\title{
Do Saudi Learners of English Recognize the Benefits of Consciousness-raising Tasks and Communicative Tasks?
}

\author{
Adnan Mukhrib ${ }^{1}$ \\ ${ }^{1}$ English Language Center, Umm AL Qur'a University, Makkah, Saudi Arabia \\ Correspondence: Adnan Mukhrib, English Language Center, Umm AL Qur'a University, Makkah, Saudi Arabia
}

Received: April 25, 2020

Accepted: May 30, 2020

Online Published: June 1, 2020

doi: 10.5539/elt.v13n6p172

URL: https://doi.org/10.5539/elt.v13n6p172

\begin{abstract}
This study examined perceptions of students of the benefits of consciousness-raising tasks (CRT) and communicative tasks (CT) when compared with actual learning outcomes in a Saudi secondary school context. Qualitative data were collected from 60 Saudi speaking learners of English, at various proficiency levels, who had engaged in a sequence of collaborative speaking and writing tasks. The results showed the value of the TBL approach which was not in question but makes a significant contribution regarding the importance of the role of interaction in mixed ability groups. The findings indicate that there was a variation in outcomes particularly in terms of how the students perceived the benefits and contribution of the intervention type to their learning. In addition, there was a further impact from the sociolinguistic context of the interaction, which indicates the role of group dynamics and individual variations of Saudi learners. This implies that fluency and accuracy during sociolinguistic interaction is influenced by a wide range of features than cannot be assessed through traditional fluency measures alone. The findings therefore lend support for a TBL approach to maintain the development of fluency, accuracy, and learning.
\end{abstract}

Keywords: communicative, consciousness raising, interaction, spoken production, written production

\section{Introduction}

As Saudi Arabia engaged in an on-going programme of expansion and development as a global power, English is now viewed as increasingly important and is thus compulsory at all educational stages (Alrashidi \& Phan, 2015; Mauranen et al., 2010). The challenge for researchers in the field is that the majority of the studies undertaken in the country have been at the university, rather than secondary school level (Al-Hassaani, 2016; Al-Zahrani \& Rajab, 2017; Moskovsky, 2018). Furthermore, global views on the value of task-based learning (TBL) and indeed interaction have not necessarily taken into account cultural and social factors, nor those of individual speaking and learning styles and what these may mean for the perceptions of students being exposed to a new teaching approach. In the Saudi context particularly, the researchers felt that it was important to consider how to support English language teachers at the secondary level to bridge gaps in knowledge and teaching methods at the higher and adult level.

In previous works, tasks have been used as a means of encouraging spoken and written performances in second language (L2) learners, as well as a vehicle for encouraging interaction and the development of self-awareness of errors and learning opportunities (Bowles \& Adams, 2015). Furthermore, as Jong (2009) and Leki (2001) note, the creation of a natural learning environment may be important for development of fluency, accuracy and motivation for all four key skills. In this respect, there is a focus on a dialogic approach to TBL which requires on-going talk between teacher and students, encouraging active participation in learning, and as Alexander (2004) notes, requires meaningful exchanges and contributions to be made when working in a collaborative group. Tasks that place a high cognitive demand in terms of processing but are explicit are considered to be the most impactful on learning (De La Colina \& Mayo, 2007; Skehan, 1996). In other words, when the load is increased the need to discuss and negotiate understanding may be heightened.

In order to address the question of student's views on interaction as a tool for improving fluency and accuracy, our study examined learners' perceptions of both CT and CRT tasks, using the TBL approach which included group interaction and collaboration. At the same time, the study aimed to identify whether the student's perspectives are borne out by their actual learning outcomes. In this paper we provide first a theoretical and methodological overview of previous studies into the development of TBL, negotiation of meaning, group 
dynamics and comprehensible output hypothesis. This is followed by a description of our research procedures and a presentation of the results. Next, the findings of our research with reference to psycholinguistic processes of L2 production and perception are discussed. We conclude this paper by highlighting the key points relating to student perspectives and their relationship to learning outcomes before outlining future directions for research.

\section{Literature Review}

\subsection{Development of TBL}

The TBL approach was initially developed in 1980 by Prabhu and since then has undergone several evolutions, outlined in Table 1 below.

Table 1. TBL Timeline

\begin{tabular}{|c|c|c|}
\hline Author & Source and Text & Contribution to Evolution of TBL \\
\hline $\begin{array}{c}\text { Prahbu } \\
1980\end{array}$ & 'Reactions and predictions' & $\begin{array}{l}\text { Suggested that a new approach was needed to teaching that focused on } \\
\text { learning through communication rather than for communication }\end{array}$ \\
\hline $\begin{array}{c}\text { Krashen } \\
1982\end{array}$ & $\begin{array}{l}\text { Principles and Practice in Second } \\
\text { Language Acquisition. }\end{array}$ & $\begin{array}{c}\begin{array}{l}\text { Highlighted the need for meaningful communication in teaching } \\
\text { approaches }\end{array}\end{array}$ \\
\hline $\begin{array}{l}\text { Long } \\
1983\end{array}$ & $\begin{array}{c}\text { Native speaker/non-native } \\
\text { speaker conversation and the } \\
\text { negotiation of comprehensible } \\
\text { input. }\end{array}$ & $\begin{array}{l}\text { Early version of the interaction hypothesis, based on conversations } \\
\text { between native and non-native speakers for meaning negotiation }\end{array}$ \\
\hline $\begin{array}{l}\text { Long } \\
1985\end{array}$ & $\begin{array}{l}\text { A role for Instruction in Second } \\
\text { Language Acquisition }\end{array}$ & $\begin{array}{l}\text { Development and recognition of the interaction hypothesis - } \\
\text { highlighting the importance of student interaction in task }\end{array}$ \\
\hline $\begin{array}{c}\text { Swain } \\
1985\end{array}$ & $\begin{array}{l}\text { Communicative competence: } \\
\text { some roles of comprehensible } \\
\text { input and comprehensible output } \\
\text { in its development. }\end{array}$ & $\begin{array}{l}\text { Introduced the construct of comprehensible output - that L2 learners } \\
\text { will learn when they encounter a gap in their linguistic knowledge. }\end{array}$ \\
\hline $\begin{array}{c}\text { Breen } \\
1987\end{array}$ & $\begin{array}{l}\text { Learner Contributions to task } \\
\text { design. }\end{array}$ & $\begin{array}{l}\text { Identified the importance of student contribution to task design and } \\
\text { completion, confirming the important role of interaction }\end{array}$ \\
\hline $\begin{array}{c}\text { Nunan } \\
1989\end{array}$ & $\begin{array}{l}\text { Designing Tasks for the } \\
\text { Communicative Classroom }\end{array}$ & $\begin{array}{l}\text { Identified the importance of manipulation of knowledge during } \\
\text { interaction to achieve task }\end{array}$ \\
\hline $\begin{array}{l}\text { Long } \\
1991\end{array}$ & $\begin{array}{l}\text { Focus on form: A design feature } \\
\text { in language teaching } \\
\text { methodology. }\end{array}$ & $\begin{array}{l}\text { Identification of the need for focus on meaning and form, and } \\
\text { negotiation of meaning during interactions }\end{array}$ \\
\hline $\begin{array}{l}\text { Long \& } \\
\text { Grookes } \\
1992\end{array}$ & $\begin{array}{l}\text { 'Three Approaches to Task-Based } \\
\text { Syllabus Design'. }\end{array}$ & $\begin{array}{l}\text { Put forward definition of tasks, to clarify earlier perspectives and } \\
\text { incorporated the value of needs identification }\end{array}$ \\
\hline $\begin{array}{l}\text { Willis } \\
1996\end{array}$ & $\begin{array}{l}\text { A Framework for Task-Based } \\
\text { Learning. }\end{array}$ & $\begin{array}{l}\text { Put forward the notion of goal orientation in the development of tasks } \\
\text { and reinforced previous views of the social nature of learning in TBL } \\
\text { context }\end{array}$ \\
\hline $\begin{array}{c}\text { Skehan } \\
1998\end{array}$ & 'Task-based instruction'. & $\begin{array}{c}\text { Developed the Trade-Off Hypothesis which suggested there was a } \\
\text { trade-off between task complexity and accuracy }\end{array}$ \\
\hline $\begin{array}{c}\text { Skehan } \\
2001\end{array}$ & Tasks and language performance. & $\begin{array}{l}\text { Put forward the view that there should be a real world orientation in } \\
\text { the development of tasks to make them more meaningful }\end{array}$ \\
\hline $\begin{array}{l}\text { Robinson } \\
2001\end{array}$ & $\begin{array}{l}\text { Task complexity, cognitive } \\
\text { resources, and syllabus design: A } \\
\text { triadic framework for examining } \\
\text { task influences on SLA. }\end{array}$ & $\begin{array}{l}\text { Suggested that the increase in the cognitive load of a given task leads } \\
\text { to the level of accuracy and complexity but not fluency in its execution }\end{array}$ \\
\hline $\begin{array}{l}\text { Ellis } \\
2003\end{array}$ & $\begin{array}{l}\text { Task-based language learning } \\
\text { and teaching. }\end{array}$ & $\begin{array}{c}\text { Identified the difference between task-based and task supported } \\
\text { learning. }\end{array}$ \\
\hline
\end{tabular}


The evolution of TBL has been underpinned by the growing importance of a student-centered approach to learning, as well as a focus on meaningful communication, interaction and the use of real world tasks during instruction and learning. Cognition's role has also been identified regarding task complexity and how this relates to accuracy and fluency as well as the role of interaction and negotiation between students (Ellis, 2003).

Long's initial $(1985,1996)$ hypothesis suggests that interaction provides the means to negotiate meaning and thus achieve understanding of the input side of language learning as noted by Doughty \& Pica (1986) and Long (2000). Other works for example Brown (2007) identify the significance of the interpersonal context, group dynamics and personality, confirming Long's (1981) view that focused on participative discussion, particularly the constructs of input and interaction. Input in Long's theory referred to the used linguistic forms while interactions were the form's functions such as clarifications, repetition and expansion. Ellis (1991) agreed and indicated the importance of a) having comprehensible input, and b) modifying the interaction structure of communication. These views are aligned with those of Long (1996), Ellis (1994), and Krashen (1982) on comprehensible input and how important the quantity of comprehensible input is, but with no recognition of the role of social and group dynamics and individual learner perceptions. Subsequent to his initial hypothesis, Long (1989) suggested a revised version that a) although a comprehensible input facilitates SLA, it is not necessary or sufficient, and b) learners, in their interactions, are required to modify their output to facilitate the integration process, a view confirmed by Alcón and Mayo, 2008; Mackey (2007); Mackey, Oliver, and Leeman (2003); Swain and Lapkin (2001).

In essence, interactions allow learners to become aware of where there are gaps in their own interlanguage and the TL (Schmidt, 2001), this awareness in turn encourages modification of output and thus improved communicative ability as Swain (1995) noted. In other words, there is a key role for negotiation of meaning as a measure of the interaction quality. The psycholinguistic mechanisms underlying this view are that there is an interactive and compensatory focus in understanding speech, pushing learning towards attention to form and meaning and thus creation of connections within the context of interaction (through task requirements).

At the same time, as Jong (2009) notes, interaction alone may be insufficient and it is in fact the interplay of task set and demands, context, group dynamics and individual learner perceptions which have the most significant impact on outcomes. Examining the interaction perspective has put forward the view that negotiation for meaning in small groups is encouraged by a desire to make their output more comprehensible and target-like (Gass \& Mackey, 2007). This negotiation is however dependent on learners understanding the value and rationale for the interaction. These include identification of gaps in knowledge, opportunities for negotiation and output modification and increased attention to linguistic forms. In this regard, the concept of the 'pushed output' hypothesis was developed as a means of stretching students to produce the target language in improving their fluency and accuracy, through a focus on form and meaning during the interaction Swain (1985).

\subsection{Comprehensible Output Hypothesis - Definition and Evaluation}

The comprehensible output hypothesis, according to Swain $(1985,1995)$, suggests that L2 learners will learn when they notice their knowledge gap, frequently identified during interaction. The noticing does not automatically lead to language acquisition, but it is a crucial starting point, particularly during collaborative tasks, although it is unclear at present whether the noticing is conscious or subconscious. In effect, Swain (1995) suggested that an output serves three specific functions: noticing, hypothesis testing and metalinguistic reflection by the learners, but also that comprehensible input should be balanced with pushed output to increase production opportunities. Interaction may create this balance by stretching learners' knowledge. The term comprehensible input refers to language input that learners are able to make sense of even if they do not understand all the word structures. In collaborative groups, this is deemed as non-stressful as the focus is on comprehension rather than recognition of all lexical and grammatical elements of the utterance.

Similarly, Ellis (2003) and Swain (2005) recognised that pushed output reflects the output which learners can produce accurately and concisely if they are pushed into using the TL. Mackey (2007) agreed with Swain and further suggested that pushed output is a process of paraphrasing, rephrasing and reformulating the original utterances when giving feedback but which can also occur through self-monitoring. If students are motivated to achieve understanding, they will make greater efforts to rectify the gaps in their knowledge, or those of their interlocutors.

Mackey (2012) also subscribes to Nation's view and identified two types of tasks. One-way tasks are those which are non-reciprocal and the learner is given the responsibility for the bulk of the talking and transmitting of the information in the completion of the task. The second type, two-way tasks, requires an exchange of information which is important in relation to encouraging interaction. Shehadeh (2011) stated that one-way tasks 
provide an opportunity for learners to generate the pushed-out requirement rather than two-way conversations. This is also supported by Ellis (2003) because as the entire burden is placed on the learner to complete the given task, their consciousness of language is raised. This aligns with the current study in determining how students feel about the two tasks and the effects of noticing gaps in their linguistic knowledge.

\subsection{Task Based Learning and Learner Perception}

Willis (1996) suggests there are a number of stages within the TBL approach, illustrated in the figure below.

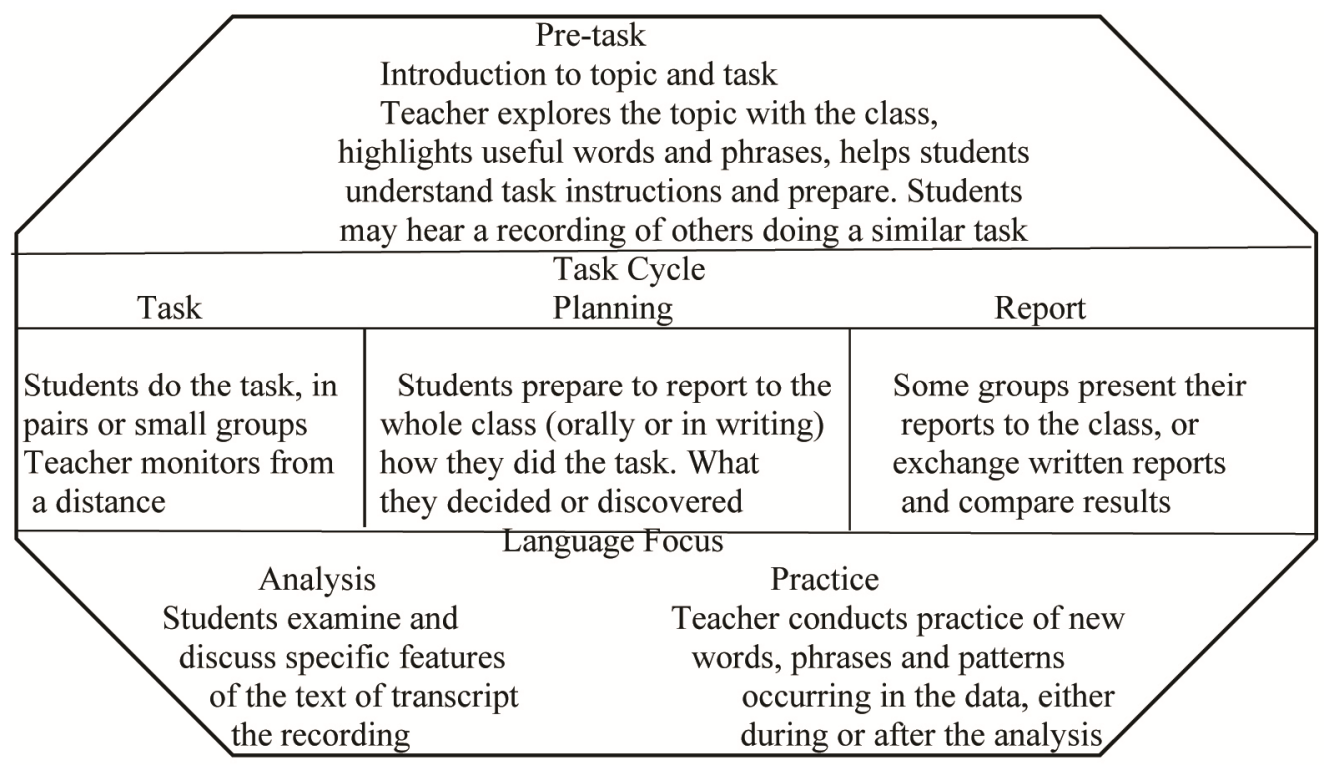

Figure 1. Stages of the task-based language learning. Adapted from Willis (1996: 132).

It appears from figure 1 that tasks can be diverse and open to teacher interpretation and student motivators, the last of these having salience for understanding the perceptions of learners and the impact of these perceptions on their learning outcomes. This reinforces the notion of TBL as a student-centered learning practice (Ellis, 2003; Nunan, 2003; Richards and Rodgers 2001). In addition, the framework identifies the importance of content-based activities which have meaning rather than being sterile grammatical forms (Carless, 2002; Littlewood, 2004). The value of TBL is, therefore that learners are given the opportunity to develop their language abilities with meaningful materials, interaction and personal development.

Moreover, crucial to the success of this approach is the motivation and engagement of the students. Without this, no meaningful discussions, or negotiation of meaning, and thus creation of learning space will occur as Stroud (2013) notes. In the Saudi context the construct of TBL and student-centered learning is unfamiliar, as the current teaching modes are teacher-led and traditionally learning is passive. Furthermore, the secondary school setting is an under-researched area of EFL in the country which could lead to challenges in terms of the learning/applications and motivation of both students and teachers. In regard to interaction and how there is a beneficial relationship between tasks and interaction, studies have considered how tasks can be used to generate talk among students to examine its effects on L2 acquisition, for more details see Stroud (2013) and Tang et al., (2015).

Examples of effective tasks can be found in the work of Willis (1996) and are shown in Table 2 below. 
Table 2. Examples of Effective Tasks

\begin{tabular}{|c|c|}
\hline Task type & Description \\
\hline Listing & $\begin{array}{l}\text { Students must work together and identify facts to achieve the specific goal which } \\
\text { completed list of their findings in the TL. }\end{array}$ \\
\hline Ordering and sorting & Including ranking, classifying, sequencing, or categorising target words. \\
\hline Comparing & $\begin{array}{l}\text { Matching phrases or words which requires identification of similarities and differences } \\
\text { by working to match phrases or words. }\end{array}$ \\
\hline Problem solving & $\begin{array}{l}\text { Examination of real world situations to arrive at hypothetical results which means the } \\
\text { students must interact, discuss and make decisions }\end{array}$ \\
\hline $\begin{array}{l}\text { Sharing of personal } \\
\text { experiences }\end{array}$ & $\begin{array}{l}\text { Description of events, or narratives from students, but also requires exploration and } \\
\text { explanation of attitudes, viewpoints and experiences. }\end{array}$ \\
\hline Creative tasks & $\begin{array}{l}\text { This may involve fact finding, brainstorming or ordering but also leads to the delivery } \\
\text { of an outcome that can then be shared with a group, }\end{array}$ \\
\hline
\end{tabular}

Source: Adapted from Willis (1996)

Subsequent definitions include that of Prabhu (1987, p. 24) who stated that a task is 'an activity which requires learners to arrive at an outcome from given information through some process of thought, and which enables teachers to regulate and control that process'. Nunan suggested that a task could be 'any structured learning endeavour which has a particular objective, appropriate content, a specified working procedure, and a range of outcomes for those who undertake the task' (Nunan, 2004, p. 3). Tasks, according to Nunan (2004), can be categorised into two broad areas, real-world tasks which involve the language uses beyond the classroom, and pedagogical tasks which refer to tasks inside the classroom. Lee (2008) suggested that no clear ideas on how a task is defined in the context of TBL really exist, nor specifically which create the best outcomes for students. However, there is agreement in the sense that they refer to the implementation of the task, rather than the task itself.

Therefore, in line with Ellis (2003), 'a task is a work plan which typically involves some input, a primary focus on meaning, it also involves real-world processes of language use and any of the four language skills and engages cognitive processes' (p. 195). Indeed, Ellis further distinguishes between those tasks which have a primary focus on encouraging understanding of meaning and those which can be classed as exercises designed to have a primary focus on forms. It is however noted that in some cases the distinction is not definitive as there may be overlapping features between the tasks and exercises which creates a further challenge in curriculum development. For this work, a task is viewed from the definition of Ellis (2003) due to the focus on interaction, consciousness raising and communicative tasks which align well with his definition. In overall terms, the functions of creation and processing during interaction therefore provide an important window into the cognitive and social processes which students undergo to develop their linguistic and communicative competence.

Recognizing the value from the students' perspective is important as Saudi Arabia is currently focused on improving English knowledge in its citizens (Alrabai, 2018; Liton, 2012). However, the teaching process and achievement of results have been hindered by a lack of authentic student relevant materials (Mitchell \& Alfuraih, 2017). This situation has been further exacerbated by numerous policy changes along with the traditional format of teaching approaches, large classes and a resistance to students taking a central role (Picard, 2018). (Bahanshal, 2013; Elyas \& Picard, 2013; Faruk, 2015). As such understanding whether CT and CRT tasks are most effective may be crucial for future planning and underlines the value and contribution of this task.

\subsection{Communicative and Consciousness Raising Tasks}

The choice of task types by the teacher may be impacted on by the desired goal and by the overall learning environment, as indicated in Figure 1 below, in terms of the concepts and roles outlined: 


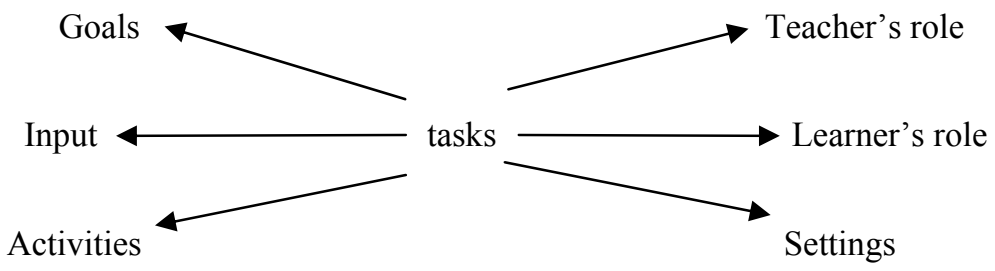

Figure 2. Framework for analysing communicative tasks (Nunan, 1989:11)

In essence a communicative task leads to negotiation of meaning, and thus understanding ( Pica, 1994; Varonis \& Gass, 1985). However, the exposure to TL, for many Saudi learners, is mainly limited to the classroom, which reinforces the potential benefits of using an interaction approach with real world tasks. A number of empirical studies (Allen \& Mills, 2016; Fujii, Ziegler \& Mackey, 2016; Pica, 2002, 2004) further suggest there is a positive impact on identification of grammatical abilities when L2 learners receive feedback on their output during interaction of a conversational nature (Ellis, 2009). Building on this knowledge, CTs have moved away from traditional grammar exercises to exploit a more communicative technique.

CRT tasks also have a role in the TBL approach. The purpose of CR tasks, as Ellis (1991) noted, is mainly intended to enhance learners' understanding of explicit knowledge of grammatical structures. Schmidt (2001), however, argued that this type of task integrates learners' attention to linguistic forms in the meaning-based activities. Ellis (2003) further suggested that the target form benefits from being isolated for focused attention in the CR approach.

Schmidt (2012) also suggests that language awareness means that learners are able to resolve linguistic forms more effectively as they identify the gaps and compare these to their current state of linguistic ability in their output and the TL input. It appears therefore that metalinguistic awareness might be helpful in combining focus on form and meaning during on-going performance (Al-Qahtani \& Lin, 2016; Jahan \& Kormos, 2015). So, a CR approach encourages self-learning and discovery through presenting tasks/problems related to grammatical structure. Clearly both CT and CRT tasks may be welcomed by students, but it is the reality of the classroom context and group dynamics that ultimately dictates which mix of tasks may be appropriate for each individual group of learners, and the social interaction the task requires (Ellis and Yuan, 2004).

In other words, task conditions which according to Samuda and Bygate (2008, p.15) refers to the ways in which external pressures (i.e. the learning environment) can be used and manipulated at different task stages. For example, placing a time pressure or indicating that students should use a combination of collaboration and completion to undertake the task are two forms of potential manipulation. This manipulation of conditions for the tasks allows a teacher to adapt and indeed direct the difficulty of the task, whilst retaining the task goal and student centered approach. In this respect, Samuda and Bygate (2008) identified a core difference between traditional drills or exercises and a task which has several phases. A phased approach means that a task can be broken down into several connected stages, making the learning more seamless and potentially less pressurised for the students, but also impacted by individual differences (Kawauchi, 2005). These differences, such as personality, proficiency and motivation can impact on whether a student decides to repair errors. In effect, there is a dynamic and interactive relationship between individual differences and L2 learning.

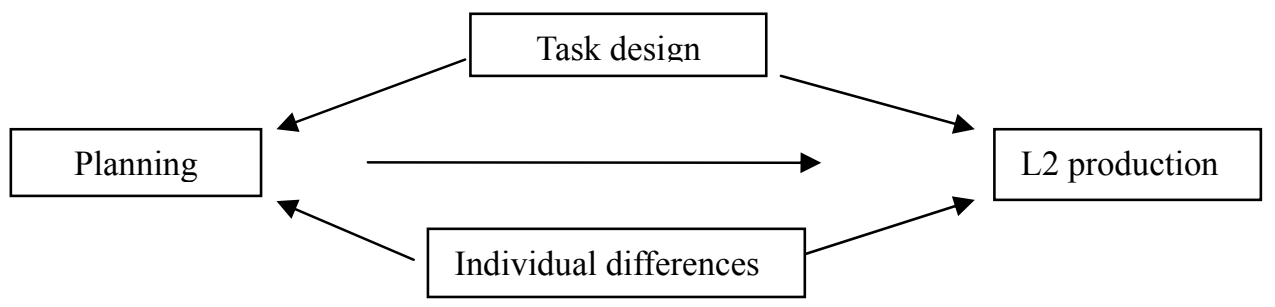

Figure 3. Framework for Investigating Individual Differences in Task-based Production

As indicated in Figure 2, there is an inter-connected relationship between the task design and individual differences which also impact on the planning that undertaken. Ahmadian (2012) and Ellis (2012) suggest that learners' evaluation of L2 fluency and accuracy (and indeed the TBL approach) may be associated with individual differences in allocating their attention. Clearly there are benefits but these need to be weighed against student perceptions as these will influence motivation, engagement and ultimately learning outcomes, which 
further underlines the rationale for this work. In order to explore a gap between conscious awareness of a given form and the ability of language learners to incorporate that form in spontaneous production in such institutions, it is therefore necessary to examine learners' perceptions on the benefits of tasks to their learning. The study was guided by the following research questions.

1) What are learners' perceptions on the benefits of CRTs and CTs to their learning?

2) What is the relationship between learners' perceptions and learning outcomes?

\section{Method}

\subsection{Setting and Participants}

This study was carried out with the use of three EFL intact classes at a typical government secondary school in Yanbu industrial city, Saudi Arabia. The cohort was comprised of 60 male Saudi EFL learners, the use existing learning groups, and instructing them to perform a sequence of tasks. Participants were all learning English as a foreign language and recruited from a secondary school as volunteers. All were aged between 17 and 18 and were studying at grade three. Arabic is their native language and they had studied English language for five years: three years in intermediate school (four classes per week) and two years in secondary schools (five classes per week).

\subsection{Research Instruments and Procedure}

The instruments used in this study are interviews, classroom observation and field notes. The data from interviews were transcribed and analysed by the main researcher. Recordings were listened to several times to achieve familiarity with the content and to conduct an initial coding that helped the process of theoretical sampling. The interviews, conducted after the intervention period, included open-ended questions and were audio-recorded and transcribed to investigate the students' perceptions of tasks and their opinions concerning task types and how they negotiated meanings and forms (Révész, 2014). All interview sessions commenced with background questions (e.g., performing tasks) before a focus on the primary areas under investigation, i.e. how students viewed the usefulness of the tasks, interactions and the influence on their learning outcomes. Interviews were conducted in Arabic then translated and coded using NVivo to identify categories and themes that could support manual evaluation and analysis. The interviews were complemented by field notes and classroom observations, in particular identification of group dynamics and individual differences based on Wilson (2017).

Consideration was given to how to provide assurances of authenticity and dependability of the opinions expressed. For this study, the inter-raters were two fellow researchers. Specifically, comparisons were made on the translations of the transcripts. To ensure $90 \%$ agreement, the refinements were made by re-listening to the transcripts and achieving agreement. Measuring inter-rater reliability in qualitative aspect can be complex as whilst similar themes may be identified, the grouping of themes may be different for each rater (Campbell et al, 2013). Discussion, review and amendment through verbal agreement on the transcript at the $90 \%$ level.

\section{Results}

In order to answer our first research question regarding leaner perceptions of the TBL approach, we examined the responses given in the interviews, for patterns, trends and both positive and negative views of the process. The interview responses indicated that many students identified a relationship between how they felt about the process and their learning outcomes, although their views were mixed as the following comment from a member of the CRT group indicates:

'It helps me to discover the information or look for it how to teach my mate and how to give the information to my mate. Repeated practice in doing CR tasks helps improve and develop the language'.

In the combined group, students indicated that it would be possible to learn something about grammar and then practice the grammatical points in communicative tasks, although one obstacle mentioned by L2 learners was that the textbook materials are inappropriate and did not appear to have a clear understanding of their progress while being taught in TBL.

I think it is very useful to be aware of the grammar points, then we use the same points in another lesson in interaction or to describe something, but we need to finish the textbook'.

Indeed, the students in general perceived the use of CRT as having benefits in the use of pragmatic competence and the importance of grammatical structures and level of lexical items. In this respect, a number of students reported that it can be beneficial during interactive tasks to maximise and develop their interlanguage linguistic elements, which is summed up in the following comment: 
I think linguistic knowledge in CR tasks is the basis of pragmatic competence. The learners may not organize the interactions without a high level of vocabulary items and grammar'.

However, students in the CT condition highlighted that communicative tasks provide them with more opportunities to express their own opinions. They felt that taking this approach helped them identify gaps in their knowledge, which suggests that the process leads to an increase in 'the cognitive mapping among forms, meaning, and use' (Doughty, 2001, p. 211), which may contribute to L2 development. In addition, it highlights the importance of self-recognition of fluency which as Tavakoli and Hunter (2018), is often neglected in work by teachers as specific learning outcome. In other words, offering students the opportunity to self-correct and encourage them to develop improved fluency.

This suggests that CT and CR tasks are considered by the students as beneficial to L2 development in terms of expanding their knowledge and ability although there was still a desire to ensure the full curriculum was covered. A surprising outcome was the students' response to the explanation of grammatical rules in English. In the case of the CR task, the students perceived the task type as interesting and that they understood me clearly when explaining these details in English as the following comments highlight. The first quote indicates how the students recognize the benefits of task-based teaching in terms of recall and understanding despite a focus on English.

'There are some differences between task-based approach and the previous one. First, I have now the ability to remember the information. Second, as a result of grammar teaching as soon as we finish CR tasks it is interesting, and I have the ability to understand even though the researcher used only English to explain all the points'.

For this student, there was a similar positive view on the opportunity for interactions and opportunities to use English and gain new knowledge as indicated in the following comment:

'It is a kind of change - I haven't seen this before - whereas the traditional approach is normal and routine, we only know that the teacher explains and assigns homework. There was no discussion and no tasks, and no group work. The teacher only wants to cover the material - they don't provide an opportunity for students to use English. Changing the group's members and have interactions with unfamiliar students as well as report what the previous speakers have said was very nice and interesting to talk with new group members".

For this student, it appeared that the learning experience was positive, and a welcome change from traditional learning. It is also noted that the positive feelings extended to a view that their learning improved by interacting with unfamiliar peers to resolve the tasks.

"When being asked to express our opinions and start to think, we use our own words and then we find that some words are missing that we really need to know. This is a good reason that makes us learn such as picture-description tasks. We have more opportunities to focus on grammar points during communicative tasks, produce the written form and then go back to what we have already performed'.

These views suggest that in general terms the students welcomed the TBL approach and felt that it provided a more positive learning environment, where they developed their language skills and comprehension of key elements of the language necessary for communicative competence. In other words, in relation to RQ1, it appears the overall view is positive. However, it is also evident that some students still take a passive position in the TBL approach. This may be due to the fact that traditional teacher-fronted activities have led classroom instruction in Saudi Arabia, which has prevented the achievement of communicative competence. Moreover, the extent and significance of this positive view has been difficult to verify, given the small size of the sample.

In general, the emergent themes from the evaluation of the semi-structured interviews were that the students felt positively about the approach, although there was some hesitation due to a lack of familiarity with the process of task-based pedagogy. At the same time, there was recognition of the benefits that could be achieved in fluency, accuracy and confidence should the approach be implemented as a standard teaching practice. There were indications that the group interactions supported increased understanding but in an engaging and creative way. Similar indications and themes emerged during the classroom observations. However, it is not fully clear whether the improved outcomes are due solely to the interventions or whether there is concurrent impact from improved motivation. Further investigation is therefore needed to assess the significance of the relationship between the intervention types (task type) and student perceptions of the TBL approach.

In regards to RQ2, i.e. whether there was a connection between the students' views and their learning outcomes, and whilst the significance of the identified relationship was difficult to measure due to the small sample, the following comment indicates how learners felt about this issue: 
'It helps me to discover the information or look for it how to teach my mate and how to give the information to my partner. Repeated practice in doing CR tasks helps improve and develop the language'.

However, a comment from the field notes suggests that there was some reticence about the process, and its effect on learning, as indicated by the following excerpt from the field notes:

'Some students did not want to explore knowledge themselves and find their own answers, or do not like to develop their communicative abilities'.

Therefore, alongside the responses from the students there were also some general observations made regarding the overall interaction and response to the tasks and the processes. For example, it was observed that some students talk off-task and have an exclusive focus on the L1 to produce more negotiation about meaning or forms Overall, however, it was clear that there was a perceived benefit to the use of CRT and CR tasks in improving outcomes. These students' perspectives were complemented by classroom observations and field notes.

One clear observation was that the Saudi students did not actually plan but instead tried to read the instructions and do the tasks immediately. It seemed that they had a lack of transfer from the pre-task phase to the actual performance, which may contribute to a lower level of performance (Skehan, 2014). It was also noted that the students had a positive attitude towards collaborative tasks, which supported interaction with the researcher and facilitated classroom observation.

Given that this study was also recognized as a learning process about interactions classroom observations were used to provide a more holistic look at the overall process. Observing and taking notes over a four-week period meant the researchers could more readily understand the context of the learning environment. L2 learning is seen as a social process and interaction has an important role to play in the building of linguistic knowledge and completing the tasks (Johnson, 2006), which underlines the value of group work in the language classroom. There was also some confusion expressed about the tasks and the overall interaction, in particular, how much they could use the L1, as the following overheard exchange illustrates:

Extract

L1: should we speak with English all the time or.

L2: that's up to you

L3: I think I think so that is why it's recorded

L1: we know that we're recorded

This suggests that the students may have felt some pressure to focus on English and that the recording of their work and interactions was part of their assessment. In this respect, it was also observed that, during task-based interactions, there was pausing, frustration, signs of hesitation, repeating or correcting an utterance and lexical retrieval difficulty. When this became laborious, it appeared that the students simply switched to the mother tongue if they were unable to recall the appropriate words to express what they want to say. To highlight the difficulties reported by the students, the following sections provide an overall summary of the comments from the three groups that were recorded during the sessions and subsequently transcribed.

\section{CRT Group:}

'I was doing this but I was not sure entirely, I don't know if I was right. At some points I got confused whether I was doing right?'

'He is asking us to formulate the rule...how we work out the rule ourselves'.

In this group, there is some evidence of confusion about the task, although the second interlocutor in the group appeared to provide clarification, suggestion that the confusion about the task components and requirements was not universal. This highlights the importance of collaboration, for those who understand and can support others, can increase the learning and comprehension when the task is confusing and/ or challenging. In this view, the interactions can support the successful completion of the task and a reduction of concerns which can then increase aspects of fluency and accuracy.

CT Group:

'I looked at the picture but I was worried about the grammatical structure if it was.' .

'I guess it was confusing as to what tense it was supposed to be used. I think I thought it was supposed to be the present tense'.

'I was trying to decide on how we can put unrelated pictures together to construct a story'. 


\section{'I was looking at the pictures and it was a challenge to put them in order'.}

In this group as well, the clear implications were that they found the task challenging, confusing and they were concerned about getting it right. This additional pressure, potentially caused by a lack of understanding about the task, has already been highlighted as an issue that may have contributed to reducing performance by this group.

Combination Group:

for this one I was struggling for words. Sometimes higher proficiency students interrupted me and I forgot what I wanted to say'.

'I remember thinking about the answer. I didn't know.. I wanted to give the answer differently. I was thinking of different adjectives/nouns'.

In the final group, the concern did not appear to be about the nature of the tasks, instead the focus was on getting the work right. It is however interesting to note that the first participant in this exchange indicated that they were prevented from dealing with the tasks due to the interaction with more proficient students. What this suggests is that the management and dominance of the conversation in the interactions need to be carefully handled by the teacher or facilitators in the classroom to ensure equal participation by all group members involved in line with Hung et al., (2015) and Wang (2014).

Observing the students' interaction as they struggled to complete the task and learned about their cognitive capacity also highlighted the aspects they needed to develop further. It is however noted that there is a potential impact on the students from the observer effect, which may affect the validity and reliability of observational data (Cohen et al., 2013). This means that there may be an alteration in the learners' behaviour due to being observed. To reduce this effect and further support validity, additional field notes were taken immediately after the sessions. Undertaking this approach means that recall of observations is not affected by the time delay and inaccurate recall.

Alongside these observations, there were also some general observations made regarding the overall interaction and response to the tasks and the processes. For example, it was observed that some students talk off-task and have an exclusive focus on the L1 to produce more negotiation about meaning or forms. In addition, different strategies used by students across tasks suggest that frequency of use of the L1 depends on task demands. This would suggest that L1 is important as a cognitive tool for students to help one another across tasks. It was further observed that some students did not take the task seriously or perhaps did not want to explore knowledge themselves and find their own answers, or were reluctant to develop their communicative abilities, suggesting that they may need additional motivation to participate in the approach.

This variation in students' engagement and ability was also noted in relation to use of prior experience and background knowledge with some advanced students to perform the tasks. Whilst some students are fluent, they try to remember their declarative knowledge when they do CR tasks and they found new points about linguistic features. However, most students just tried to perform the tasks rather than consider what they could learn from the tasks themselves. During the performance of tasks, advanced students normally do the tasks and then sometimes explain to other students what they have done. We made some changes to the tasks because we realized that some students had difficulty understanding the instructions and what they are required to do (e.g. CRTs). In addition, we started to explain some points explicitly and give more feedback after task completion.

The analysis of the field notes generally suggested that the students in the group are on a learning curve, and it gives them a path into the future, and this provides insights into a critical event in TBL. An element of the study and the observation sessions particularly was to see how the students dealt with challenges or difficulties. Some of students reacted in a positive way. This means that they understood that their abilities could be developed, and they could have a growth mindset, due to their positive attitudes towards the situation. Others however were not yet at this stage, and thus potentially needed further encouragement to understand that learning through the TBL approach is an on-going process as Jafarpour et al., (2015) noted.

In applying the field notes to answering the RQ2, there was evidence that interaction with the main researcher can be more effective in helping L2 learners to notice a particular linguistic feature than from interlocutors especially in small group work (Nassaji, 2009). In some of the exchanges, for example, there was an attempt to gather clarification from group interaction, but the preference was for teacher clarification rather than peers, according to the following note:

'I regularly moved around the classroom and attended promptly to confused students or the ones with raised hands in order to gain a sense of the whole picture. I have observed that personal and interpersonal factors affect learner's attention to form in task-based interaction.' 
From these notes, it was identified that Saudi students do not ask each other for clarification because they prefer to take the answer from the teacher even though their interlocutor might know the answer. In addition to these findings, it was also identified that the more involved the students were with the task, the better their learning outcomes. This appears to corroborate existing works on the value of not only the TBL approach, but also the focus on CRT and CT aspects of the instruction to promote interactions, reflection and self-correction within the groups. However, it was further noted that the nature of the relationship between fluency and accuracy varied depending on the difficulty of the grammar, lexis and other features of the interaction. This would suggest that as the learner's proficiency increases, their confidence, fluency and accuracy increase.

\section{Discussion}

In this section, we discuss the results of the study in relation to our two research questions. Firstly, in regards to RQ1, the qualitative data gathered for this work has identified as a general outcome that there was a majority view that task based interaction, both CT and CRT had a positive impact on learning outcomes and this was borne out by the overall improvements identified from the students' responses. With regard to RQ2, the data analysis implied that there has been improvement, which was sustained but only for as long as the interaction and collaboration continued.

The results also indicated several interesting perspectives and potential for further investigation. For example, during the period of the intervention there were strong improvements in fluency, accuracy and motivation, but that this tailed off when the intervention ceased and there was a return to the more traditional teaching methods. This underlines the value of the interaction approach in encouraging learning, but also that the interaction needs to be on-going.

A further factor identified, based on processing load was that the students found themselves relying exclusively on L1 to ask questions, interact and negotiate answers which is in line with Swain and Lapkin (2000). The use of L1 during the interactions therefore may be a means of supporting learners with metalinguistic functions, for example solving grammatical and lexical problems, evaluating and reformulating L2 forms and achieving comprehension of L2 utterances. In support of Storch and Wigglesworth (2003) these approaches indicate that in the early stages of L2 acquisition, L1 can be used to support understanding and reduce processing load so that the task itself can be focused on. This was common amongst all groups, and also underlines that the use of L1 during the interaction supports a polite and effective working environment when there is a mixed proficiency in a group. In particular, for interpersonal relations and communication aspects of the task, not directly related to L2 output requirements, again supports the views of Storch and Wigglesworth (2003).

Advanced students also utilized L2 for interpersonal communication, indicating one of the values of the collaborative approach to tasks as this increases the use of L2 in a social context, embedding the knowledge in a more naturalistic way. This supports the view of Carless (2008) as the advanced learners used L2 as a learning system, rather than a desired output as was the case with the lower proficiency learners who relied on greater usage of L1. What was also noted in this regard was how the students themselves felt about the use of L1, and given the views of Johnson (2006) and Firth and Wagner (2007), regarding the social process of learning, the observations identified that for some students there was some confusion about not only the task requirements but also how much they could use L1. In addition, there was some initial reticence to take peer advice and feedback, preferring to refer to the teacher. However, as the intervention progressed, and the students became more familiar with the interaction/ collaboration nature of the task-based approach, they became more confident with the process, which is common when a new approach to learning is encountered as Jafarpour et al., (2015) note.

In general, the students found the task-based approach more interesting than any previous teaching approaches they had experienced. In particular, the opportunity to negotiate form, function and lexical content within a group was cited as a benefit, which aligns with prior works by Storch (2005) and others. When considering what they believed to be the primary benefits of the approach, there was variation from the groups. The CRT group felt that discovering rules for themselves supported their learning, whilst the CT group suggested a major benefit was supporting learning on how to make real-world task decisions. These two perspectives were brought together by the combined group, who felt that the combination of learning and then applying the learning in tasks was the biggest benefit.

There were, at this point however, reservations about the appropriateness of the materials and how their progress was measured. These are common threads when students are asked to reflect on TBL approaches, particularly when the process is new and unfamiliar to them as Carless (2002), Rao (2002), Savignon and Wang (2003) and Tsang (2016) note. A further benefit highlighted by the students across the groups was the contribution of the focus-on-form approach or pragmatic competence, due to the way the interactions were organized and the 
impetus this gave for utilizing a richer level of vocabulary and grammatical structures in the L2. This aligns with indications by Rajabi et al., (2016) of the pragmatic value of task-based learning, and the foundation of the approach to interaction being learning as a social process.

This social process of learning also means that there is a potential to increase confidence and motivation through task-based approaches as noted by Dörnyei (2003), Oxford (2006) and Finch (2008) and certainly this view was confirmed by many of the students across all groups. However, the observations also raised some questions about measurement of fluency which need to be further explored. For example, it was identified that lengthening reflects breakdowns and a reduced linguistic retrieval. In other words, pause length may not be a viable measure of breakdown fluency, as it can be influenced by individual speaking style. Additionally, the hesitations, pauses etc. may be a part of their natural style or may be related to struggling with grammar/vocabulary. There is also a potential that there is content related hesitation, with the pauses being used to give the students time to think before responding. Whilst these questions could not be answered in the context of the current study, they do raise important questions which need further exploration.

The fact that the groups were mixed ability meant that those with higher lexical knowledge could support learning in lower proficiency and shared grammatical knowledge could be used by the whole group in the completion of the tasks. In this respect as Lehtonen (2000) indicates the group ability differences when working together support growth in confidence and motivation, and this appeared to be the case for the learners in this study. Similarly, there also appeared to be a level of consciousness raising through collaboration in order to complete the tasks, which supports the work of Ellis (2003) and Nunan (2004) regarding unconscious benefits of group work and interaction in TBL. More conscious benefits included elevated levels of self-awareness.

The increased self-awareness led to improved ability to self-correct during both spoken and written outputs underlining the contribution of the task-based approach to metacognitive development. No significant distinctions were identified between the groups in relation to these benefits, suggesting that across the board, the TBL and interactive approach were positively received which is an encouraging finding for Saudi secondary schools. There were however some indications that whilst the written tasks were interesting and beneficial, the spoken tasks were considered more valuable to the group, particularly for the CT respondents, who cited more time for pronunciation practice and feedback as a primary benefit of the approach. The rationale for this is that the learners felt more confident of their pronunciation and thus more likely to take opportunities to use L2 in real life situations.

\section{Conclusion}

Reviewing the overall outcomes, the students believed that the benefits were numerous and there is thus agreement with the view of Johnson (2006) the TBL learning environment, irrespective of task, encouraged greater attention to different features of language including grammar, lexis and pragmatics. Grammar learning in particular was considered to be supported by the process, and given that for many the intervention period was the first time they had been able to really listen to their L2 output, and then evaluate and critique it in a supportive environment, this indicates a clear benefit to the process. In regard to group dynamics and in line with Fujii et al., (2016) students had a preference for small groups over pairs, believing the variations in proficiency and confidence supported learning. In contrast to the views on speaking tasks, the students had a preference to undertake writing tasks individually. The rationale for this is that less time was available to ensure everyone participated. This appears to align with individual variations and confidence as noted by Afshar \& Ramini (2016) and Jonassen \& Grabowski (2012). No major negatives were raised other than concerns about measurement of progress and group dynamics. We suggest the results are cautiously considered since we acknowledge the current study has some limitations in relation to wider application, due to the small scale and the challenges of manually calculating fluency and accuracy ratios within the groups at each stage.

It is also important to note that the positive views of the process suggest that the students' perceptions, and therefore attitudes are linked to better learning outcomes in a TBL focused intervention. In the CT group particularly, there was a view that the nature of the tasks, for example the written work, encouraged improved writing, but also listening and speaking skills due to the discussions with peers after the individual written task and before the group task. Furthermore, echoing findings from Samuda \& Bygate (2008), and Kaplan \& Maehr (2002) the increased imitation, recitation, and opportunity to use interlanguage encourage use of new ideas relating to form, function and pragmatic understanding. In terms of the task types, CR tasks were considered beneficial for negotiation of grammatical structures, whilst the CRT was deemed more effective in error identification and recognition development. The only note of dissent in relation to this was from lower proficiency students who felt that if the basic rules were not already known, it would take longer to complete the 
task. In essence, challenges were grounded in their own proficiency and confidence, reinforced by the identification of the value of L1 usage for lower proficiency students during the interactions.

Overall, the results have indicated that there is real potential to introduce the TBL approach to the EFL classes in Saudi Arabia, despite some reservations about adherence to textbooks and curricula, and the impact of group dynamics. Not only could it improve confidence and motivation to study what is a mandatory subject, but could also enhance outcomes in terms of rich vocabulary use, embedded grammatical knowledge and pragmatic competence. It is however recognized that there may be further research required in the area, in particular the identified variation in lexical access and L2 fluency between CT and CR tasks and the indication that processing load of CT tasks better support correct resolution of LREs. We argue, however, there are clear indications that interactive tasks can make a positive contribution to the teaching of EFL in Saudi secondary schools.

\section{Acknowledgements}

We are grateful to English Language Teaching editors and two anonymous reviewers for their invaluable feedback on an earlier version of the manuscript. We would also like to thank Talia Isaacs for her helpful comments and support, and to all the learners who participated in the study.

\section{References}

Afshar, H. S. \& Rahimi, M. (2016). Reflective thinking, emotional intelligence, and speaking ability of EFL learners: Is there a relation? Thinking Skills and Creativity, 19, 97-111. https://doi.org/10.1016/j.tsc.2015.10.005

Ahmadian, M. J. (2012). The Relationship between Working Memory Capacity and L2 Oral Performance under Task-Based Careful Online Planning Condition. TESOL Quarterly, 46(1), 127-147. https://doi.10.1002/tesq.8

Alcón, E. \& García Mayo, M. P. (Eds.). (2008). Focus on form and learning outcomes with young learners in the foreign language classroom. Amsterdam John Benjamins. https://doi.10.6018/ijes.7.2.48981

Alexander, R. (2004). Dialogic Teaching and the Study of Classroom Talk. In International Conference keynote address, 44(3), 103-111. https://doi.10.2167/le778.0

Al-Hassaani, A. (2016). A Case Study of Question Formations of the Saudi EFL Learners at Bisha University. English Language Teaching, 9(5), 54-64. https://doi.10.5539/elt.v9n5p54

Allen, D. \& Mills, A. (2016). The impact of second language proficiency in dyadic peer feedback. Language Teaching Research, 20(4), 498-513. https://doi.10.1177/1362168814561902

Al-Qahtani, A. \& Lin, M. (2016). The Impact of Creative Circles on EFL Learners' Reading Comprehension. Theory and Practice in Language Studies, 6(8), 15-19. https://doi.10.17507/tpls.0608.01

Alrabai, F. (2018). Learning English in Saudi Arabia. In English as a Foreign Language in Saudi Arabia. 110-127. Routledge.

Alrashidi, O. \& Phan, H. (2015). Education Context and English Teaching and Learning in the Kingdom of Saudi Arabia: An Overview. English Language Teaching, 8(5), 33-44. https://doi.10.5539/elt.v8n5p33

Al-Zahrani, N. O. A. \& Rajab, H. (2017). Attitudes and Perceptions of Saudi EFL Teachers in Implementing Kingdom of Saudi Arabia"e s Vision 2030. world, 5(1).

Bahanshal, D. (2013). The effect of large classes on English teaching and learning in Saudi secondary schools English Language Teaching, 6(11), 49. https://doi.10.5539/elt.v6n11p49

Bowles, M. A. \& Adams, R. J. (2015). An Interactionist Approach to Learner-learner Interaction in Second and Foreign Language Classrooms. In the Handbook of Classroom Discourse and Interaction. 198-212. John Wiley \& Sons, Inc.

Breen, M. P. (1987). Learner Contributions to task design. In C.N. Candlin \& D. Murphy (Eds.). Lunca.srer Practical Papers in English Language Education. Vol. 7. Language Learning Tasks, 23-46. Englewood Cliffs, NJ: Prentice Hall.

Brown, H. D. (2007). Principle of language learning and teaching ( $5^{\text {th }}$ eds). White Plains, NY: Pearson Longman.

Campbell, J. L., Quincy, C., Osserman, J. \& Pedersen, O. K. (2013). Coding in-depth semi-structured interviews: Problems of unitization and intercoder reliability and agreement. Sociological Methods \& Research, 42(3), 294-320. https://doi.org/10.1177/0049124113500475 
Carless, D. (2002). Implementing task-based learning with young learners. ELT Journal, 56(4), 389-396.

Carless, D. (2008). Student use of the Mother tongue in the Task based Classroom. ELT Journal, 62(4), 331-338. Cohen, L., Manion, L. \& Morrison, K. (2013). Research methods in education. Oxon: Routledge.

De la Colina, A. \& Mayo, M. G. (Eds.). (2007). Attention to form across collaborative tasks by low-proficiency learners in an EFL setting. In M. P. Garcia' Mayo (ed.), investigating tasks in formal language learning. London, UK: Multilingual Matters.

Dörnyei, Z. (2003). Attitudes, orientations, and motivations in language learning: Advances in theory, research, and applications. Language Learning, 53(S1), pp. 3-32. https://doi.10.1111/1467-9922.53222

Doughty, C. (2001). The cognitive underpinnings of focus on form. In P. Robinson (Ed.). Cognition and secondlanguage instruction. 206-257. Cambridge: Cambridge University Press.

Doughty, C. \& Pica, T. (1986). Information gap tasks: An aid to second language acquisition? . TESOL Quarterly, 20(2), 305-325. https://doi.org/10.1017/S027226310606013X

Ellis, R. (1991). Grammar teaching practice or consciousness-raising? In R. Ellis (Ed.), Second Language Acquisition and Second Language Pedagogy. 232-241. Clevedon, Avon: Multilingual Matters.

Ellis, R. (1994). The study of second language acquisition. Oxford: Oxford University Press.

Ellis, R. (2003). Task Based Language Teaching and Learning. Oxford: Oxford University Press.

Ellis, R. (2009). Task-based language teaching: sorting out the misunderstandings. International Journal of Applied Linguistics, 19(3), 221-243. https://doi.10.1111/j.1473-4192.2009.00231.x

Ellis, R. (2012). Language Teaching Research and Language Pedagogy. Hoboken: Wiley-Blackwell.

Ellis, R. \& Yuan, F. (2004). The effects of planning on fluency, complexity, and accuracy in second language narrative writing. Studies in Second Language Acquisition. Studies in Second Language Acquisition, 26(01), 59-84. https://doi.10.1017/S0272263104026130

Elyas, T. \& Picard, M. (2013). Critiquing of higher education policy in Saudi Arabia: towards a new neoliberalism. Education, Business and Society: Contemporary Middle Eastern Issues, 6(1), 31-41. https://doi.10.1108/17537981311314709

Faruk, S. M. G. (2015). Winds of change in Saudi English textbooks: A cultural perspective. Sino-US English Teaching, 12(7), 524-538. https://doi.10.17265/1539-8072/2015.07.008

Firth, A. \& Wagner, J. (2007). Second/foreign language learning as a social accomplishment: Elaborations on a reconceptualized SLA. The Modern Language Journal, 91(s1), 800-819. https://doi.10.1111/j.1540-4781.2007.00670.x

Finch, A. (2008). An attitudinal profile of EFL learners in Korea. Electronic Journal of Foreign Language Teaching, 5(2), 206-219.

Fujii, A., Ziegler, N. \& Mackey, A. (Eds.). (2016). Peer interaction and metacognitive instruction in the EFL classroom. Amsterdam: John Benjamins.

Gass, S. \& Mackey, A. (2007). Input, interaction, and output in second language acquisition. In B. Vanpatten \& J. Williams (Eds.). Theories in second language acquisition (pp. 175-200). London: LEA.

Hung, H., Young, S. \& Lin, C. (2015). No student left behind: a collaborative and competitive game-based learning environment to reduce the achievement gap of EFLstudents in Taiwan. Technology, Pedagogy and Education, 24(1), 35-49. https://doi.10.1080/1475939X.2013.822412

Jafarpour, A., Mirzaei, A. \& Ehsani, F.Z. (2015). Collaborative L2 Interactivity in Diverse ZPD-Based ProximalContexts and Interactional Competence Development. Journal of Teaching Language Skills, 6(3), 75-100.

Jahan, A. \& Kormos, J. (2015). The impact of textual enhancement on EFL learners' grammatical awareness of future plans and intentions. International Journal of AppliedLinguistics, 25(1), 46-66. https://doi.10.1111/ijal.12049Johnson, K. (2006). The sociocultural turn and its challenges for second language teacher education. TESOL Quarterly, 40(1), 235-257. https://doi.10.2307/40264518

Jonassen, D. \& Grabowski, B. (2012). Handbook of individual differences, learning, and instruction. Routledge. 
Jong, Y.O. (2009). An investigation into the benefits of collaborative writing for the development of EFL children's communication skills: A reflective report of a teacher researcher (Doctoral dissertation, University of Warwick).

Kaplan, A. \& Maehr, M.L. (2002). Adolescents' Achievement Goals: Situating Motivation in Sociocultural Contexts.In F. Pajares \& T. Urdan (Eds.). Academic motivation of adolescents (pp.125-167). Oxford: Information Age Publishing.

Kawauchi, C. (Ed.) (2005). The effects of strategic planning on the oral narratives of learners with low and high intermediate levels of L2 proficiency. Amsterdam and Philadelphia: John Benjamins.

Krashen, S. (1982). Principles and Practice in Second Language Acquisition. Oxford: Pergamon Press.

Lee, I. (2008). A Practical Guide to a Task-Based Curriculum: Planning, Grammar Teaching and Assessment. Hong Kong: City University of Hong Kong Press.

Lehtonen, T. (2000). Awareness of strategies is not enough: How learners can give each other the confidence to use them. Language Awareness, 9(2), 64-77. https://doi.org/10.1080/09658410008667138

Leki, I. (2001). "A narrow thinking system": Nonnative-English-speaking students in group projects across the curriculum. TESOL quarterly, 35(1), 39-67. https://doi.10.2307/3587859

Liton, H. (2012). Developing EFL Teaching and Learning Practices in Saudi Colleges: A Review. Online Submission, International Journal of Instruction, 5(2), 129-152. https://doi.10.4324/9781315688466-5

Littlewood, W. (2004). The task-based approach: some questions and suggestions', ELT Journal, 58(4), pp. 319-326. https://doi.org/10.1093/elt/58.4.319

Long, M. H. (1981). Input, interaction and second-language acquisition. In H. Winitz (Ed.). Native language and foreign language acquisition: Vol. 379. Annals of the New York Academy of Sciences pp.259-278. New York: New York Academy of Sciences.

Long, M. H. (1983). Native speaker/ non-native speaker conversation and the negotiation of comprehensible input. Applied Linguistics, 4(2). 126-141.

Long, M. H. (1985b). A role for Instruction in Second Language Acquisition: Task-Based Language Teaching. In K. Hystelstam \& M. Pienemann (Eds.). Modeling and accessing Second Language Acquisition. Cleverdon, UK: Multilingual Matters.

Long, M. H. (1989). Second language research: some implications for methodology and class size in teaching Japanese. AJALT Journal, 12, 22-31. https://doi.10.1007/978-94-6300-325-4

Long, M. (1991). Focus on Form: A Design Feature in Language Teaching Methodology. In K. De Bot, R. Ginsberg \& C. Kramsch (Eds.). Foreign Language Research in Cross-Cultural Perspectives (pp. 39-52). Amsterdam: John Benjamins.

Long, M. H. (1996). The role of the linguistic environment in second language acquisition. In W. C. Ritchie \& T. K. Bhatia (Eds.). Handbook of second language acquisition (pp. 413-468). New York: Academic Press.

Long, M. H. \& Crookes, G. (1992). Three Approaches to Task-Based Syllabus Design. TESOL Quarterly, 1(26), 27-56. https://doi.10.2307/3587368

Mackey, A. (2007). Interaction as practice. In R. DeKeyser (ed.). Practice in a second language: Perspectives from applied linguistics and cognitive psychology. 85-110. Cambridge: Cambridge University Press.

Mackey, A. (2012). Input, interaction and corrective feedback in second language classrooms. Oxford: OxfordUniversity Press

Mackey, A., Oliver, R. \& Leeman, J. (2003). Interactional Input and the Incorporation of Feedback: An Exploration of NS-NNS and NNS-NNS Adult and Child Dyads. Language Learning, 53(1), 35-66. https://doi.10.1111/1467-9922.00210

Mauranen, A., Hynninen, N. \& Ranta, E. (2010). English as an academic lingua franca: The ELFA project. English for Specific Purposes, 29(3), 183-190. https://doi.10.35360/njes.108

Mitchell, B. \& Alfuraih, A. (2017). English language teaching in the Kingdom of Saudi Arabia: Past, present and beyond. Mediterranean Journal of Social Sciences, 8(2), 317. https://doi.10.5901/mjss.2017.v8n2p317

Moskovsky, C. (2018). EFL teaching and learning in Saudi Arabia: 25 years of research. In English as a Foreign Language in Saudi Arabia (pp. 12-77). Routledge. 
Nassaji, H. (2009). Effects of recasts and elicitations in dyadic interaction and the role of feedback explicitness. Language Learning, 59(2), 411-452. https://doi.10.1111/j.1467-9922.2009.00511.x

Nation, I.S.P. (2011). Second language speaking. In E. Hinkel (Ed.). Handbook of research in second language teaching and learning (pp.445-454). New York: Routledge.

Nunan, D. (1989). Designing Tasks for the Communicative Classroom. Cambridge: Cambridge University Press.

Nunan, D. (2003). The impact of English as a global language on educational policies and practices in the Asia-Pacific Region. TESOL quarterly, 37(4), 589-613. https://doi.10.2307/3588214

Nunan, D. (2004). Task Based Language Teaching. Cambridge: Cambridge University Press.

Oxford, R. (2006). Task-based language teaching and learning: An overview. Asian EFL Journal, 8(3), 94-121.

Pica, T. (1994). Research on negotiation: What does it reveal about second-language learning conditions, $\begin{array}{llll}\text { processes, and } \quad \text { Lutcomes? } & \text { Language }\end{array}$ https://doi.org/10.1111/j.1467-1770.1994.tb01115.x

Pica, T. (2002). Subject matter content: How does it assist the interactional and linguistic needs of classroom language learners? Modern Language Journal, 86(1), 1-19. https://doi.10.1111/1540-4781.00133

Pica, T. (2004). Second language acquisition research and applied linguistics. In E. Hinkel (Ed.). Handbook on second language learning and teaching (pp. 263-280). Mahwah, NJ: Erlbaum.

Picard, M. (2018). The future of EFL and TESOL in Saudi Arabia. In English as a Foreign Language in Saudi Arabia (pp. 165-185). Routledge.

Prahbu, N. S. (1980). Reactions and predictions. [Special issue]. Bulletin, 4(1). Bangalore: Regional Institute of English, South India

Rajabi, L., Mehrdad, A. \& Karimi, L. (2016). Investigating The Effect Of Opinion-Gap Tasks On English as A Foreign Language Learners' pragmatic Competence. Modern Journal of Language Teaching Methods, 6(2), 509.

Rao, Z. (2002). Chinese students' perceptions of communicative and non-communicative activities in EFL classroom. System, 30(1), 85-105. https://doi.10.1016/S0346-251X(01)00050-1

Révész, A. (2014). Task - Based Learning: Research Methods. The Encyclopedia of Applied Linguistics.

Richards, J. \& Rodgers, J. (2001). Approaches and Methods in Language Teaching. Cambridge: Cambridge University Press.

Robinson, P. (2001). Task complexity, task difficulty, and task production: exploring interactions in a componential framework. Applied Linguistics, 22(1), 27-57. https://doi.10.1093/applin/22.1.27 •

Samuda, V. \& Bygate, M. (2008). Tasks in second language learning. Basingstoke: Palgrave Macmillan.

Savignon, S. \& Wang, C. (2003). Communicative language teaching in EFL contexts: Learner attitudes and perceptions. International Review of Applied Linguistics, 41(3), 223-250. https://doi.10.1515/iral.2003.010

Schmidt, R. (2001). Attention. Cognition and second language instruction. Cambridge: Cambridge University Press.

Schmidt, R. (Ed.) (2012). Attention, awareness, and individual differences in language learning. Boston: MA: Mouton de Gruyter.

Shehadeh, A. (2011). Effects and student perceptions of collaborative writing in L2. Journal of Second Language Writing, 20(4), 286-305. https://doi.10.1016/j.jslw.2011.05.010

Skehan, P. (1996). A framework for the implementation of task-based instruction. Applied linguistics, 17(1), 38-62. https://doi.10.1093/applin/17.1.38

Skehan, P. (1998). A cognitive approach to language learning. Oxford. Oxford University Press.

Skehan, P. (2001). Tasks and language performance. Researching pedagogic tasks: Second language learning, teaching, and testing, 167-185.

Skehan, P. (2014). Limited attentional capacity, second language perfocmence, and task-based pedagogy. In Skehan (Ed.) (pp. 211-260).

Storch, N. \& Wigglesworth, G. (2003). Is there a role for the use of the L1 in an L2 setting? TESOL Quarterly, 37(4), 760-769. https://doi.10.2307/3588224 
Storch, N. (2005). Collaborative writing: Product, process, and students' reflections. Journal of Second Language Writing, 14(3), 153-173. https://doi.org/10.1016/j.jslw.2005.05.002

Stroud, R. (2013). Increasing and maintaining student engagement during TBL. Asian EFL Journal, 59, 28-57.

Swain, M. (1985). Communicative competence: Some rules of comprehensible input and comprehensible output in its development. In S. Gass \& C. Madden (Eds.). Input in second language acquisition (pp. 235-253). Rowley, MA: Newbury House.

Swain, M. (1995). Three functions of output in second language learning. In G. Cook \& B. Seidhofer (Eds.). For H. G. Widdowson: Principles and practice in the study of language. Oxford: Oxford University Press.

Swain, M. (2005). The output hypothesis: Theory and research. In E. Hinkel (eds.). Handbook of Research in Second Language Teaching and Learning. London: Routledge. 471-484

Swain, M. \& Lapkin, S. (2000). Task-based second language learning: The uses of the first language. Language Teaching Research, 4(3), 251-274. https://doi.10.1177/136216880000400304

Swain, M. \& Lapkin, S. (2001). Focus on form through collaborative dialogue: exploring task effects. Research in exploring pedagogic tasks. London Longman.

Tang, H., Chiou, J. S. \& Jarsaillon, O. (2015). Efficacy of Task-Based Learning in a Chinese EFL Classroom: ACase Study. English Language Teaching, 8(5), 168-176. https://doi.10.5539/elt.v8n5p168

Tavakoli, P., Hunter, A.M. (2018). Is fluency being 'neglected' in the classroom? Teacher understanding of fluency understanding of fluency and related classroom practices. Language Teaching Research, 22(3), 330-349. https://doi.org/10.1177/1362168817708462

Tsang, C. (2016). Factors influencing ESL learners' perceptions towards a task-based approach to speaking: Secondary school students' perspectives from Hong Kong (Doctoral dissertation). Hong Kong Institute of Education.

Varonis, E. \& Gass, S. M. (1985). Non-native/non-native conversations: a model for the negotiation of meaning. Applied Linguistics, 6(1), 71-90. https://doi.org/10.1093/applin/6.1.71

Wang, Y. (2014). Using wikis to facilitate interaction and collaboration among EFL learners: A social

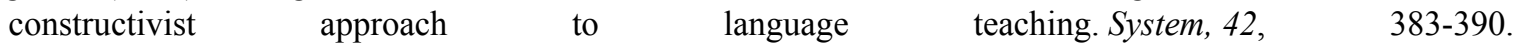
https://doi.org/10.1016/j.system.2014.01.007

Willis, J. (1996). A Framework for Task-based Learning. London, England: Longman Publishing.

Wilson, E. (2017). School Based Research: A Guide for Education Students. London: Sage. 


\section{Appendices}

Appendix A

Student Interview Questions

\section{Interviews include a number of different questions}

1) Can you tell me about your learning experience of English?

2) Have you ever been to any English-speaking country? Where?

3) What skill do you think is most important/ difficult?

4) What are your overall feelings about task-based learning?

5) I see. So what are your impressions of this task?

6) Are there some changes in your feelings toward a task?

7) Which task do you perceive as the most difficult, easiest, and most interesting? Why?

8) What factors do you think contribute to this difficulty?

9) How useful you found the variety of tasks?

10) So how did the tasks in the study help you improve your English?

11) What are your feelings on your spoken/writing tasks?

12) Do you prefer to work in pairs, individually, or in a small group? Why?

13) How helpful is it to work with other students during the tasks?

14) How did you negotiate meaning/ form with your partners?

15) Right, how did you feel about working with higher/ lower proficiency learners?

Can you give me more details and why?

16) Can you explain the advantages and disadvantages of group work?

17) What do you think about the researcher's intervention while doing a task?

18) Can you tell me about the difficulties or challenges you encountered during task performance?

19) Are there any differences before and after your participation in this study?

20) Do you have any comment or suggestions? 
Appendix B

Sample field notes

Task type:

Date:

My notes

In session two, the students were searching appropriate words to perform the task successfully. Some 'lower proficiency students' use words with similar meaning or the words used by higher proficiency students, and observe others how they perform the tasks without involvement, but they just take the answer or how the grammatical structures work.

Whilst some students were fluent, they tried to remember their declarative knowledge while doing CR tasks and they found new things about linguistic features. However, they used their prior experience just to complete the task.

L1: $\quad$ isn't that present?

T: Yeah

L2: $\quad$ why we put 'excited -ed?

T: Yeah, that's a good question.mm. Try to think about why they're using excited/ bored not boring/ exciting (0.1) so is it about how people feel?

L2: $\quad$ Mm. maybe!

T: $\quad$ how she's feeling, rather than things or situation

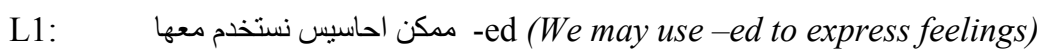

T: for example: 'the students are confused' expresses that how they feel

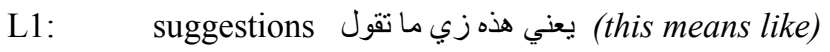

L3: $\quad$ isn't surprised, interesting حيث يعني ممكن يكون (it means this may be...)

L1: $\quad$ is not surprising

You have a very interesting question

My comments

In the CRT group, some students asked themselves how they formulate the rules and this task design is new for them. Some did not want to explore knowledge themselves and find their own answers, or do not like to develop their communicative abilities.

The CRT students talk about the language and it is not necessary to produce sentences include the linguistic feature, so they don't frequently pause and they focus on problem-solving. Their turns can also be short during the interactions but the students try to develop their explicit understanding of the grammatical structures (e.g. the verb tenses). The students (e.g. CT group) might produce more pauses or make changes to what is being said. They had to generate the content and cognitively match the content with the linguistic feature.

The students started to think of lexical items in-depth and plan what they want to say to their interlocutors, and they had different opportunities to use English.

\section{Copyrights}

Copyright for this article is retained by the author(s), with first publication rights granted to the journal.

This is an open-access article distributed under the terms and conditions of the Creative Commons Attribution license (http://creativecommons.org/licenses/by/4.0/). 